\title{
The Protective Efficacy of Selected Phytonutrients on Liver Enzymes of Albino Rats Exposed To Cement Dust
}

\author{
Yahaya $^{1}$.T, J. Okpuzor ${ }^{1}$ and T. Ajayi ${ }^{2}$ \\ ${ }^{\prime}$ department Of Cell Biology And Genetics, Uiversity Of Lagos \\ ${ }^{2}$ department Of Chemical Engineering, Uiversity Of Lagos.
}

\begin{abstract}
The efficacy of roselle, moringa, ginger and 'ugwu' in protecting the levels of some liver enzymes of albino rats exposed to cement dust was evaluated. The rats were grouped into six containing 15 rats each. The rats in the test groups were treated with $400 \mathrm{mg} \mathrm{kg}{ }^{-1}$ ethanol extracts of roselle, moringa, ginger, 'ugwu' and a mixture of the plant extracts, respectively. The control rats received only distilled water $(10 \mathrm{ml}$ per day). The activities of Alanine amino Transferase (ALT), Aspartate Amino Transferase (AST), and Alkaline Phosphates activity (ALP) were monitored for a period of 180 days. Significant differences $(p<0.05)$ exist between the control and test rats in all the tested liver enzymes. The elevated liver enzymes of the control rats released into the blood stream may be due to liver damage. The fairly-normal levels of the liver enzymes of the test rats may be credited to the protective effects of the plant extracts. The results of the study underscored the efficacy of phytonutrients in reducing the effects of environmental pollutants on rats.
\end{abstract}

Keywords: cement dust, liver enzymes, albino rat, phytonutrient, pollutant.

\section{Introduction}

Plants have been used for medicinal purposes long before recorded history. Ancient Chinese texts and Egyptian papyri writings describe medicinal uses for plants as early as 3,000 BC. Africans and Native Americans used herbs in their healing rituals, while others developed medical systems such as Ayurveda and Chinese medicine in which herbal therapies were used (Steven, 2011). Plant medicine has, however, practically vanished with the evolution of modern medicine and synthetic drugs (Wu et al,. 1996). Due to public dissatisfaction with the cost of prescription medications, combined with an interest in returning to natural remedies, there has been an increase in herbal medicine use (Steven, 2011). People are returning to plant-based medicines because they are safer than synthetic drugs (Joy et al., 2010). Fortunately, plant medicine rebirth is occurring at a time during which industrial societies are battling the effects of environmental pollution.

Nearly all industries generate hazardous waste substances, and the cement industry is one of the seventeen most environmentally polluting industries listed by the United States Central Pollution Control Board (Worrell et al., 2001). During the last decades, the emission of dust and gases from cement industries has increased alarmingly due to expansion in the cement industries to meet the high demand of cement for infrastructure (Raajasubramnran et al., 2011). There is, however, a major negative impact of these dust and gas emissions because of the toxic elements they contain (Bilen, 2010). Cement dust contains calcium, silicon, aluminum, manganese, zinc, and iron (Fell et al., 2010). In addition, cement dust produced from kilns burning hazardous wastes as fuels may contain heavy metal, dioxin, particulate, and chromium. The burning of waste as fuels and calcination of limestone may also produce sulphur dioxide, nitrogen dioxide, and carbon dioxide (AdeAdemilua and Obalola, 2008; Akinola et al., 2008; Gbadebo and Bankole, 2007). The majority of these elements, when above regulatory limits, become potentially harmful to the biotic and abiotic components of the environment. These elements also have been implicated in many diseases, including respiratory, genetic, and blood diseases, skin and eye defects, multiorgans damage, and cancer (Meo, 2004).

Despite the health hazards of cement dust, cement remains indispensable in the building industry attributable to its superiority to other materials. In fact, its discovery by a British bricklayer, Joseph Aspdin, in 1824 , marks a turning point in history owing to the availability, durability, and reliability of cement compared to previously available building materials (Carey, 2005). Therefore, the health hazards attributed to cement dust must be mitigated in order to sustain the growth of the cement industry.

Several strategies have been employed to solve the effects of cement dust exposure. These methods include using efficient dust-filters and dust-collectors, planting trees to serve as dust- stoppers, planning settlements outside the coverage areas of cement dust, and using modern machines and technologies. Other methods include using synthetic detoxifiers (for example, milk and multivitamins), and incorporation of legislation against using hazardous waste as fuel (Singh and Pandey, 2011). But most of these strategies have not recorded much success (Mojimoniyi et al, 2007). The failures of these strategies are due to the lack funds, strategy technicality, weak environmental protection laws, and the nondisclosure attitudes of some cement 
manufacturers (Briggs, 2003). Consequently, pollution from cement plants remains a persistent problem with attendant health risks.

However, archaeological evidence shows that some plants such as milk thistle (Silybum marianum), red clover (Trifolium pratence), and dandelion (Taraxacum officinale) have been used to prevent or remove toxins from the body (Mindell, 1992). Milk thistle has been used for more than 2, 000 years as an herbal remedy for various ailments, particularly liver and gall bladder disorders. Several studies suggest that substances in milk thistle, especially a flavonoid called Silymarin, can protect the liver from toxins. Silymarin has antioxidant and antiinflammatory properties and may help the liver repair itself by growing new cells. Laboratory studies also suggest that Silymarin and other active substances in milk thistle may have anticancer effects, which can stop cancer cells from dividing and reproducing (Agarwal, et al., 2006). Moreover, red clover contains isoflavone, which might help protect against heart disease, stop cancer cells from growing, treat skin problems, and stop coughing (Kuhn and Winston, 2008). The dandelion also has antioxidant properties, and its roots and leaves are used to treat liver, kidney, skin, and eye problems. Therefore, there is an urgent need to evaluate the potential of some phytonutrients for reducing the effects of cement dust on humans and animals living near cement factories.

\section{Animal Husbandry}

\section{Materials}

One hundred and fifty albino rats weighing between 185 and $200 \mathrm{~g}$ were sourced from the Department of Biochemistry, University of Ibadan in August 2009. The rats were made to acclimatize to the ambient environment for seven days before commencing the research. Pellet feeds from the F. A Feeds industry, AgegeLagos and water were given to the rats ad libitum.

\section{Source of the Plant Materials}

The plant materials- roselle, moringa, ginger and 'ugwu' were purchased from Ketu in Lagos metropolis, Nigeria. They were identified by a curator, Mr. Odewo T. Kolawole, in the Department of Botany, University of Lagos. The voucher numbers of the authenticated samples are LUH 4394, LUH 4558, LUH 4396 and LUH 4395 for roselle, moringa, ginger, and 'ugwu', respectively.

\section{Preparation of the Plant Materials}

Fresh leaves of the individual plant materials were washed gently to remove impurities and air-dried under shade for one week. The dried leaves were milled into a powder using laboratory mill, Norris Limited, Poole, England at the Department of Pharmacognosy, University of Lagos. A mixture of the individual plant materials was also obtained by mixing the four parts each of the ground plant materials in the ratio 1:1:1:1. The ground plant materials were then stored in desiccators before use.

\section{Preparation of the Plant Extracts}

The bioactive compounds were extracted from the plant materials using the method of Okigbo and Ogbonnaya (2006). Fifty grams (50 g) powder of each plant material and the mixture were put in $500 \mathrm{ml} 95 \%$ cold ethanol and was allowed to stand for 72 hours. The extracts thus obtained were filtered with muslin cloth and evaporated to dryness at a temperature of $40 \pm 2^{\circ} \mathrm{C}$. The resulting dried extracts of each plant material yielded $6.6 \mathrm{~g}, 6.5 \mathrm{~g}, 6.2 \mathrm{~g}, 5.9 \mathrm{~g}$, and $6.1 \mathrm{~g}$ of roselle, moringa, ginger, 'ugwu' and mixture, respectively. These dry extracts were reconstituted in water and were the decoctions used for the experiment.

\section{Acute Toxicity Test}

The acute toxicity of the crude extracts of the plants was measured using the 'Classical $\mathrm{LD}_{50}$ ' method described by Gabriel et al. (2008). Albino rats (36) of both sexes weighing between 183 and $205 \mathrm{~g}$ were used for the studies. The rats were randomly distributed into six groups of 6 rats each and were denied food and water 12 hours before commencing the study. The control group received only distilled water, and the test groups were orally administered doses of 200, 400, 500, 700, 1500, and $2000 \mathrm{mg} \mathrm{kg}^{-1}$ of the crude extracts. The general symptoms of toxicity were monitored and recorded for each group within 24 hours. The rats were given the extracts at a dose of $400 \mathrm{mg} \mathrm{kg}^{-1}$ as indicated by Adedapo et al. (2009).

\section{Methods}

\section{Study Design}

The rats were placed into six groups of 18 rats each. Group one was the control, and groups two through six formed the test rats. The entire rats were exposed to cement dust at a cement factory in Shagamu, Ogun state, Nigeria. The activities of ALT, AST and ALP in the rats were evaluated using standard protocols, before commencing the experiment. The test rats were then treated with ethanol extracts of roselle, moringa, 
ginger, 'ugwu' and a mixture of the plant extracts, respectively. The control rats received only distilled water. The activities of ALT, AST and ALP in the rats were again monitored for 180 days.

\section{Liver Enzymes Studies}

The activities of the enzymes in the exposed rats were carried at the Biochemistry Department, National Institute of Medical Research, Yaba, Lagos.

\section{Determination of Alanine amino Transferase (ALT)}

The ultraviolet method described by Bergmeyer and Bernt (1974) was used to determine ALT activity using Randox test kits (RANDOX laboratories, Crumlin, Antrim, UK). The reagent for ALT assay composes of Phosphate buffer containing L-alanine and $\alpha$-oxoglutarate. ALT activity was measured by monitoring the concentration of pyruvate hydrazone formed with 2, 4- dintrophenyl hydrazine. The absorbance of the sample was read against the reagent blank.

$\alpha$ - oxoglutarate $+\mathrm{L}$ - alanine $\longrightarrow \mathrm{L}$ - glutamate + pyruvate

Enzyme activity is expressed as a Standard International Unit (U/I).

\section{Determination of Aspartate Amino Transferase (AST)}

The blood serum was extracted into plain bottles after centrifugation of the blood samples at 3,500 rpm for 10 minutes. AST activity was determined by the Coloremic method using Randox test kits as described by Bergmeyer and Bernt (1974). Reagent blank was prepared with $0.5 \mathrm{ml}$ of phosphate buffer containing Laspartate and $\alpha$-oxoglutarate and $0.1 \mathrm{ml}$ of distilled water. The reagent was stirred and incubated for 30 minutes at $37^{\circ} \mathrm{C}$. After incubation, $0.5 \mathrm{ml}$ of 2,4 - dinitrophenyl hydrazine was added and allowed to stand for 20 minutes at $20^{\circ} \mathrm{C}$. The serum $(0.1 \mathrm{ml})$ was then added to $0.5 \mathrm{ml}$ of phosphate buffer as described above, $0.5 \mathrm{ml}$ of 2,4 - dinitrophenyl hydrazine was also added to reagent blank and sample, respectively. The absorbance of the sample was read against the reagent blank after 5 minutes at $546 \mathrm{~nm}$.

$\alpha$ - oxoglutarate $+\mathrm{L}$-aspartate $\mathrm{L}$-glutamate + oxalocetate.

Enzyme activity is expressed as a Standard International Unit (U/I).

\section{Determination of Alkaline Phosphates activity (ALP)}

The ALP activity was determined by the spectrophotometric method according to Bergmeyer and Bernt (1974) using Randox test kits. The serum $(0.02 \mathrm{ml})$ was added to $1.0 \mathrm{ml}$ of reagent containing diethanol - amine buffer, $\mathrm{pH}$ 9.9, Magnesium Chloride $\left(\mathrm{Mg} \mathrm{Cl}_{2}\right)$ and Substrate (pnitrophenyl phosphate). The mixture produced was stirred and absorbance taken after 1, 2, and 3 minutes using a timer at $405 \mathrm{~nm}$ in a spectrophotometer. Change in absorbance taken after 2 and 3 minutes was used to determine the final absorbance of ALP.

Enzyme activity was expressed as a Standard International Unit (U/I).

\section{STATISTICAL ANALYSIS}

The Statistical Package for Social Sciences (SPSS) version 17 for windows was used for all analysis. Comparison of data between the test and control groups was calculated using Student's t-test. p $<0.05$ was considered statistically significant.

\section{Acute Toxicity Test}

\section{Results}

The results of the acute toxicity test showed the plant extracts were nontoxic to the rats even at a dose of $2000 \mathrm{mg} \mathrm{kg}^{-1}$. The general observations showed no mortality occurred 24 hours after administering the plant extracts. However, the rats that received roselle extract displayed a readiness to take more, and were licking the cannular used to administer the extract. The rats that received ginger, moringa, 'ugwu' and mixture extracts did not show any signs of illness.

\section{Efficacy of the Plant extracts on the Liver Enzymes of the Exposed Lab Rats.}

Tables 1-3 show the bioprotective efficacy of the plant extracts in the liver enzymes of the exposed rats. The test rats showed mild to moderate levels of the liver enzymes compared to the control rats. Table 1 shows the control rats had an $18.2 \mathrm{u}^{-1}$ ALT increase, whereas the rats fed with roselle, moringa, ginger, 'ugwu', and mixture extracts had 12.9, 9.9, 6.2, 7.1 and $4.6 \mathrm{u} \mathrm{l}^{-1}$ ALT increases, respectively. The AST increase in the control rats is $16.2 \mathrm{u} \mathrm{l}^{-1}$, whereas the rats administered with roselle, moringa, ginger, 'ugwu', and mixture extracts had AST increases of 14.2, 10.1, 7.4, 10.2 and $7.9 \mathrm{u} \mathrm{l}^{-1}$, respectively (Table 2). Table 3 shows the ALP 
increase of the control rats is $125.3 \mathrm{u}^{-1}$, while the ALP increases of the rats fed with roselle, moringa, ginger, 'ugwu', and mixture extracts are 45.7, 27.3, 35.0, 43.0 and $24.6 \mathrm{u} \mathrm{l}^{-1}$, respectively.

Figures 1-3 are graphical representations of bioprotective efficacy of the plant extracts on albino rats exposed to cement dust for 180 days. The test rats had a significant $(p<0.05)$ higher percentage of bioprotective efficacy compared to the control. Significant differences $(p<0.05)$ were also observed in the percentage bioprotective efficacy of the test rats.

Table 1: The ALT level (u/l) of the exposed albino rats treated with different plant extracts for 180 days

\begin{tabular}{|c|c|c|c|c|c|c|c|}
\hline Day & $\mathbf{0}$ & 90 & 180 & $\begin{array}{l}\text { Min. } \\
\text { Value }\end{array}$ & $\begin{array}{l}\text { Max. } \\
\text { Value }\end{array}$ & $\begin{array}{c}\text { Amount } \\
\text { Increase }\end{array}$ & RDL Range \\
\hline \multicolumn{8}{|l|}{ Extract } \\
\hline Control & $\begin{array}{r}25.3^{\mathrm{a}} \\
\pm 2.1\end{array}$ & $\begin{array}{r}31.1^{\mathrm{b}} \\
\pm 4.5\end{array}$ & $\begin{array}{l}43.5^{\mathrm{a}} \\
\pm 5.1\end{array}$ & 23.1 & 45.5 & $\begin{array}{l}18.2 \\
\pm 3.0\end{array}$ & $10-40$ \\
\hline Roselle & $\begin{array}{r}27.4^{\mathrm{a}} \\
\pm 3.3\end{array}$ & $\begin{array}{l}30.6^{\mathrm{b}} \\
\pm 4.04\end{array}$ & $\begin{array}{r}40.3^{\mathrm{a}} \\
\pm 5.5\end{array}$ & 25.7 & 43.6 & $\begin{array}{l}12.9 \\
\pm 2.2\end{array}$ & $10-40$ \\
\hline Moringa & $\begin{array}{r}23.5^{\mathrm{a}} \\
\pm 2.9\end{array}$ & $\begin{array}{r}27.3^{\mathrm{a}} \\
\pm 4.4\end{array}$ & $\begin{array}{r}33.4^{\mathrm{b}} \\
\pm 4.6\end{array}$ & 22.4 & 35.1 & $\begin{array}{c}9.9 \\
\pm 1.5\end{array}$ & $10-40$ \\
\hline Ginger & $\begin{array}{r}26.4^{\mathrm{a}} \\
\pm 3.3\end{array}$ & $\begin{array}{r}30.6^{\mathrm{a}} \\
\pm 3.5\end{array}$ & $\begin{array}{r}32.6^{\mathrm{a}} \\
\pm 4.0\end{array}$ & 24.3 & 34.9 & $\begin{array}{c}6.2 \\
\pm 0.9\end{array}$ & $10-40$ \\
\hline 'Ugwu' & $\begin{array}{r}26.6^{\mathrm{a}} \\
\pm 2.1\end{array}$ & $\begin{array}{r}30.5^{\mathrm{a}} \\
\pm 4.0\end{array}$ & $\begin{array}{r}33.7^{\mathrm{a}} \\
\pm 4.4\end{array}$ & 24.1 & 35.0 & $\begin{array}{c}7.1 \\
\pm 2.3\end{array}$ & $10-40$ \\
\hline Mixture & $\begin{array}{l}25.5^{\mathrm{a}} \\
\pm 3.2\end{array}$ & $\begin{array}{l}27.9^{\mathrm{a}} \\
\pm 4.5\end{array}$ & $\begin{array}{l}30.1^{\mathrm{a}} \\
\pm 5.6\end{array}$ & 24.1 & 29.0 & $\begin{array}{c}4.6 \\
\pm 2.2\end{array}$ & $10-40$ \\
\hline
\end{tabular}

- Data are expressed as Mean $\pm \mathrm{SE}$

- Mean values with different superscripts ' $a$ ' and ' $b$ ' along the same row are significantly different at $\mathrm{P}$ $<0.05$

- $\mathrm{RDL}=$ Randox Laboratory Services, UK.

Table 2: The AST level (u/l) of the exposed albino rats treated with different plant extracts for 180 days

\begin{tabular}{|c|c|c|c|c|c|c|c|}
\hline Day & $\mathbf{0}$ & 90 & 180 & $\begin{array}{l}\text { Min. } \\
\text { Value }\end{array}$ & $\begin{array}{l}\text { Max. } \\
\text { Value } \\
\end{array}$ & $\begin{array}{c}\text { Amount } \\
\text { Increase }\end{array}$ & RD L Range \\
\hline \multicolumn{8}{|l|}{ Extract } \\
\hline Control & $\begin{array}{l}26.1^{\mathrm{a}} \\
\pm 4.3\end{array}$ & $\begin{array}{l}35.8^{\mathrm{b}} \\
\pm 5.2\end{array}$ & $\begin{array}{l}42.3^{\mathrm{a}} \\
\pm 5.1\end{array}$ & 25.2 & 43.1 & $\begin{array}{l}16.2 \\
\pm 1.8\end{array}$ & $10-34$ \\
\hline Roselle & $\begin{array}{l}25.9^{\mathrm{a}} \\
\pm 5.0\end{array}$ & $\begin{array}{l}30.2^{\mathrm{b}} \\
\pm 6.1\end{array}$ & $\begin{array}{l}40.1^{\mathrm{a}} \\
\pm 4.4\end{array}$ & 24.9 & 39.2 & $\begin{array}{l}14.2 \\
\pm 1.8\end{array}$ & $10-34$ \\
\hline Moringa & $\begin{array}{l}26.3^{\mathrm{a}} \\
\pm 5.4\end{array}$ & $\begin{array}{l}28.9^{\mathrm{a}} \\
\pm 4.7\end{array}$ & $\begin{array}{l}36.4^{\mathrm{b}} \\
\pm 4.6\end{array}$ & 25.1 & 37.0 & $\begin{array}{l}10.1 \\
\pm 1.7\end{array}$ & $10-34$ \\
\hline Ginger & $\begin{array}{l}27.5^{\mathrm{a}} \\
\pm 4.2\end{array}$ & $\begin{array}{l}30.8^{\mathrm{a}} \\
\pm 5.1\end{array}$ & $\begin{array}{l}34.9^{\mathrm{a}} \\
\pm 4.8\end{array}$ & 26.0 & 35.4 & $\begin{array}{c}7.4 \\
\pm 1.1\end{array}$ & $10-34$ \\
\hline 'Ugwu' & $\begin{array}{l}25.8^{\mathrm{a}} \\
\pm 5.3\end{array}$ & $\begin{array}{l}28.1^{\mathrm{a}} \\
\pm 6.0\end{array}$ & $\begin{array}{l}36.0^{\mathrm{b}} \\
\pm 5.0\end{array}$ & 24.8 & 37.8 & $\begin{array}{l}10.2 \\
\pm 1.9\end{array}$ & $10-34$ \\
\hline Mixture & $\begin{array}{l}26.4^{\mathrm{a}} \\
\pm 4.0\end{array}$ & $\begin{array}{l}28.1^{\mathrm{a}} \\
\pm 5.0\end{array}$ & $\begin{array}{l}34.3^{\mathrm{a}} \\
\pm 5.3\end{array}$ & 25.7 & 35.3 & $\begin{array}{c}7.9 \\
\pm 2.1\end{array}$ & $10-34$ \\
\hline
\end{tabular}

- Data are expressed as Mean $\pm \mathrm{SE}$

- Mean values with different superscripts ' $a$ ' and ' $b$ ' along the same row are significantly different at; $P$ $<0.05$.

- $\mathrm{RDL}=$ Randox Laboratory Services, UK. 
The Protective Efficacy Of Selected Phytonutrients On Liver Enzymes Of Albino Rats Exposed To

Table 3: The ALP level (u/l) of the exposed albino rats treated with different plant extracts for 180 days

\begin{tabular}{|c|c|c|c|c|c|c|c|}
\hline Day & 0 & 90 & 180 & $\begin{array}{c}\text { Min. } \\
\text { Value }\end{array}$ & $\begin{array}{c}\text { Max. } \\
\text { Value }\end{array}$ & $\begin{array}{l}\text { Amount } \\
\text { Increase }\end{array}$ & RDL Range \\
\hline \multicolumn{8}{|l|}{ Extract } \\
\hline Control & $\begin{array}{l}53.7^{\mathrm{a}} \\
\pm 3.21\end{array}$ & $\begin{array}{l}89.3^{\mathrm{b}} \\
{ }^{ \pm} 1.15\end{array}$ & $\begin{array}{l}179.0^{\mathrm{a}} \\
\pm 21.7\end{array}$ & 48.4 & 188.2 & $\begin{array}{l}125.3 \\
\pm 18.1\end{array}$ & $44-147$ \\
\hline Roselle & $\begin{array}{l}57.3^{\mathrm{a}} \\
\pm 4.04\end{array}$ & $\begin{array}{l}73.3^{\mathrm{a}} \\
\pm 15.5\end{array}$ & $\begin{array}{c}103^{\mathrm{a}} \\
\pm 15.3\end{array}$ & 55.5 & 110 & $\begin{array}{l}45.7 \\
\pm 9.3\end{array}$ & $44-147$ \\
\hline Moringa & $\begin{array}{l}55.7^{\mathrm{a}} \\
\pm 5.68\end{array}$ & $\begin{array}{l}62.3^{\mathrm{a}} \\
\pm 4.16\end{array}$ & $\begin{array}{l}83.0^{\mathrm{b}} \\
\pm 8.74\end{array}$ & 49.0 & 88.9 & $\begin{array}{l}27.3 \\
\pm 5.8\end{array}$ & $44-147$ \\
\hline Ginger & $\begin{array}{l}53.0^{\mathrm{a}} \\
\pm 1.00\end{array}$ & $\begin{array}{l}64.7^{\mathrm{b}} \\
\pm 1.15\end{array}$ & $\begin{array}{c}88^{\mathrm{b}} \\
{ }^{ \pm} 4.58\end{array}$ & 50.1 & 95.3 & $\begin{array}{c}35 \\
\pm 6.1\end{array}$ & $44-147$ \\
\hline 'Ugwu' & $\begin{array}{l}53.0^{\mathrm{a}} \\
\pm 2.65\end{array}$ & $\begin{array}{l}62.3^{\mathrm{b}} \\
\pm 2.52\end{array}$ & $\begin{array}{l}96.0^{\mathrm{a}} \\
{ }^{ \pm} 1.51\end{array}$ & 49.2 & 101.2 & $\begin{array}{c}43 \\
\pm 9.7\end{array}$ & $44-147$ \\
\hline Mixture & $\begin{array}{l}54.1^{\mathrm{a}} \\
\pm 3.25\end{array}$ & $\begin{array}{l}63.7^{\mathrm{b}} \\
\pm 1.53\end{array}$ & $\begin{array}{l}78.7^{\mathrm{a}} \\
\pm 3.23\end{array}$ & 51.6 & 87.3 & $\begin{array}{l}24.6 \\
\pm 4.6\end{array}$ & $44-147$ \\
\hline
\end{tabular}

- Data are expressed as Mean \pm SE

- Mean values with different superscripts ' $a$ ' and ' $b$ ' along the same row are significantly different at $\mathrm{P}<0.05$.

- $\quad \mathrm{RDL}=$ Randox Laboratory Services, UK.

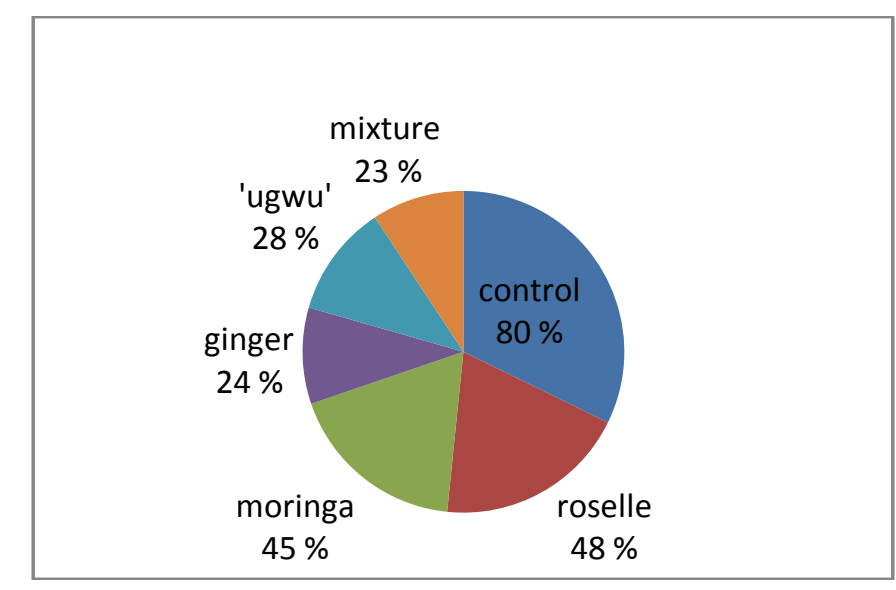

Figure 1: Percentage ALT increase (u/l) of the exposed albino rats treated with the plant extracts for 180 days.

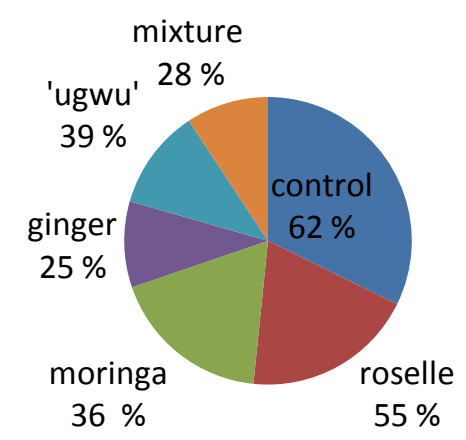

Figure 2: Percentage AST increase (u/l) of the exposed albino rats treated with the plant extracts for 180 days. 


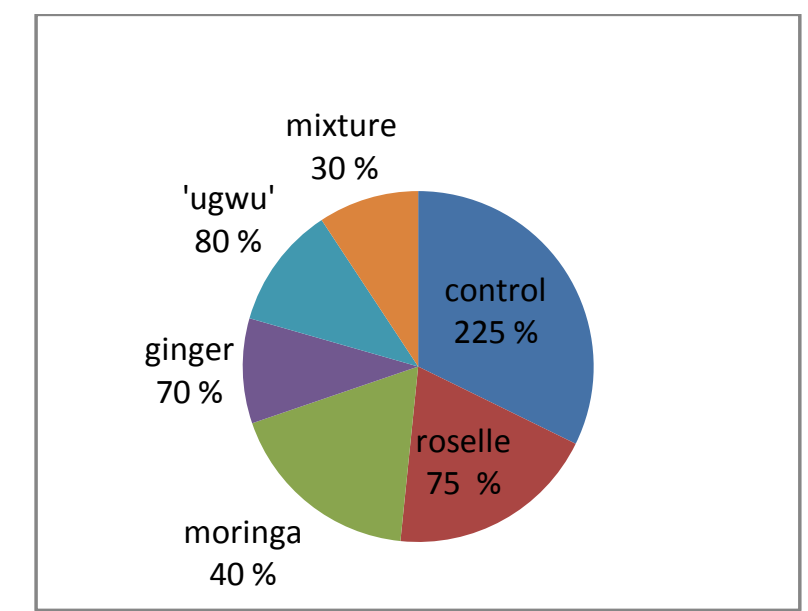

Figure 3: Percentage ALP increase (u/l) of the exposed albino rats treated with the plant extracts for 180 days.

\section{Discussion}

The abnormal levels observed in the liver enzymes, Alanine amino transferase (ALT), Aspartate amino transferase (AST) and Alkaline phosphates activity (ALP) of the control rats that received distilled water only could have stemmed from liver damage caused by toxic elements in the cement dust. These enzymes are mostly found in the liver cells, which release them into the blood stream when there is injury (Dan, 2011). Mild to moderate levels observed in the test rats compared to the control rats may be owing to the scavenging and antioxidant activities of flavonoids, tannins, glycosides, saponins, reducing sugar, and phlobatanins found in the plant extracts. All these phytochemicals could have protected the liver tissues from free-radicals damage, and worked for the overall well-being of the rats. Hepatoprotective effects of 'ugwu' plants have been reported by Iweala and Obidoa (2009). Janakat and Nassar (2010) also reported the aqueous extract of Terfezia claveryi almost normalized the effect of carbon tetrachloride $\left(\mathrm{CCl}_{4}\right)$ on liver function enzymes of albino rats as a result of the high antioxidants present in the plant. Milk thistle (Silybum marianum), containing flavonoids, has demonstrated the ability to normalize liver enzyme levels in participants whose liver had been damaged by toxic chemicals (Steven, 2011).

\section{Conclusion}

The study has shown the phytonutrients could help ameliorate or reduce the effects of cement dust on liver enzymes of rats exposed to cement dust. Therefore, the inhabitants of such places should be advised on the importance of including these phytonutrients in their diet. These phytonutrients could also be produced in forms to be taken as daily supplements for their overall well being.

\section{References}

[1] Ade-Ademilua, O.E. and D.A. Obalola. 2008. The effect of cement dust Pollution on Celosia argentea (Lagos Spinach) plant. Journal of Environmental Science and Technology. 1: 47-55.

[2] Adedapo, A.A., O.M. Mogbojuri and B.O. Emikpe. 2009. Safety evaluations of aqueous extracts of the leaves of Moringa oleifera in rats. Journal of Medicinal Plants Research. 3(8):586-591.

[3] Agarwal, R., C. Agarwal, H. Ichikawa, R.P. Singh and B.B. Agarwal. 2006. Anticancer potential of Silymarin: from bench to bed side. Anticancer Research. 26(6B):4457-4498.

[4] Aisegbu, J. E. 1987. Some biochemical evaluation of fluted pumpkin seeds. Journal of Science, Food and Agriculture. 40: 151-155.

[5] Akinola, M.O., N.A. Okwok and T. Yahaya. 2008. The effects of cement dust on Albino rats (Rattus norvegicus) around West African Portland cement Factory in Sagamu, Ogun State, Nigeria. Research Journal of Environmental Toxicology. 2(1):1-8.

[6] Anderson, D.M.C. and P.C. Bell. 1986. The gum exudates from Chloroxylon swietenia, Sclerocarya caffoa, Azadirachta indica and Moringa oleifera. Phytochemistry. 25(1): $247-249$.

[7] Bergmeyer, H.U. and E. Bernt. 1974. In: Methods of Enzymatic Analysis; Bergmeyer, H.U., 2nd ed.; Academic Press: New York, NY, Vol. 2, Pp 574-579

[8] Bilen, S. 2010. Effects of cement dust pollution on microbial properties and enzyme activities in cultivated and no-till soils. African Journal of Microbiological Research. 4: 2418-2425.

[9] Briggs, D. 2003. Environmental pollution and global burden of disease. British Medical Bulleting. 68(1): 1- 24.

[10] Carey, A. 2005. The mix-master. The Age Company Limited. http://www.theage. com.au/articles/2005/05/21/1116533577851.html. (Accessed on 10/04/2011).

[11] Dan, H. 2011. Glutathione Benefits - Disease Protection! www.Aging-No-More.com. Accessed on 15/02/ 2012.

[12] ELLMAN, G. L. 1959. Tissue sulfhydryl groups. Journal ofS Biochemistry and Biophysics. 82:70-77

[13] Fell, K.M.A., L.I.B. Sikkeland, M.V. Svendson and J. Kongerad. 2010. Airway inflammations in cement production workers. Occupational and Environmental Medicine. 67: 395-400.

[14] Gabriel, O., N. Harrision, O. Okey and A. Ukoha. 2008. Changes in Lipid and Haematological Profile of Aqueous Ethanolic Extracts of Alstonia boonei in rats. The internet Journal of Haematology. 4:1 
[15] Gbadebo, A.M. and O.D. Bankole. 2007. Analysis of Potentially Toxic Metals in Airborne Cement Dust around Sagamu, Southwestern Nigeria. Journal of Applied Science. 7(1):35-40.

[16] George, K. J. (2000). "History, Strains and Models". The Laboratory Rat (Handbook of Experimental Animals). Gillian R. Bullock (series ed.), Tracie bunton (series ed.). Academic Press. Pp. 3-16. ISBN 012426400X

[17] Harper, W.D. 2011. The Phytonutrients Revolution: How Newly Discovered Plant Nutrients can Heal what Ails You. http://www. advancednaturalmedicine. com/ds080311/. (Accessed on 11/28/2011.

[18] Iweala, E.J. and O. Obidoa. 2009. Some Biochemical, Haematological and Histological

[19] Responses to a long-term Consumption of T. occidentalis- supplemented diet in rats.

[20] Pakistan Journal of Nutrition. 8:1199-1203.

[21] Janakat, S. and M. Nassar. 2010. Hepatoprotective Activity of Desert Truffle (Terfezia claveryi) in Comparison with the Effect of Nigella sativa in the Rat. Pakistan Journal of Nutrition. 9 (1): 52-56

[22] Jennifer, P. 1994. Oxidative Damage in Neuro generative Diseases. Lancet. 344: 796-798

[23] Joy, P.P., J. Thomas, S. Mathew and B.P. Skaria. 2010. Medicinal Plants. In: Tropical Horticulture, vol. 2, Bose, T.K., J. Kabir, P. Das and P.P.Joy, (Eds.). Pp 449-632. Naya Prakash, Calcutta.

[24] Kuhn, M.A. and D. Winston. 2008. Herbal Therapy and Supplements. Philadelphia, Pa: Lippincott. Pp 365-369.

[25] Lanaqui, C.G., O. Lanaqui, A. Rahal, K. Harouete, D. Tripod, M. Mounassif and A.A.Yazid. 2001. Prevalence of respiratory problems in workers at two manufacturing centers of ready-made concrete in Morocco. Journal of Tuberculosis and Lung Diseases. 5: $1051-1058$

[26] Layne, E. 1957. Spectrophotometric and Turbidimetric Methods for Measuring Proteins. Methods in Enzymology. 10: 447-455.

[27] Myhrstad, M.C., H. Carlsen, O. Nordström and R. Blomhof. 2002. Flavonoids increase the intracellular glutathione level by transactivation of the $\gamma$-glutamylcysteine synthetase catalytical subunit promoter. Free Radical Biology and Medicine. 32 (5): $386-$ 393

[28] Meo, S.A. 2004. Health Hazards of cement dust. Saudi Medical Journal. 25(9):1153 - 1159

[29] Mindell, E. 1992. Earl Mindell's Herb Bible. pp304. Simon and Schuster, New York.

[30] Mojimoniyi, F.B.O, I.A. Merenu, M.T.O. Ibrahim and C.H. Njoku. 2007: The Effects of cement dust exposure on haematological and liver function parameters of cement factory workers in Sokoto, Nigeria. Nigeria Journal of Physiological Science. 23(1-2): 111 -114 .

[31] Okigbo, R. N. and N. O. Ogbonnaya. 2006. Antifrugal effects of two tropical leaf extracts (Ocinium gratissimum and Aframomum melegueta) on postharvest yam (Dioscorea spp.) rot. African Journal of Biotechnology. 5(9): 727-731

[32] Paravath, K., P. Sivakumar, M. Samesh and Sangsu. 2011. Sub-lethal effects of chromium on some biochemical profiles of the fresh water Teleost, Cyprinus carpio. International Journal of Applied Biochemistry and Pharmaceutical Technology. 2: 295-300

[33] Raajasubramanian, D., P. Sundaramoortha, L. Baskaran, K. SankarGanesh, A.L.A. Chidambaram and M. Jeganathan. 2011. Cement dust pollution on growth yield attribute of groundnut (Arachis hypogaea L). International Multidisciplinary Research Journal. 1(1):3136. http://www.irj.info/IRMJ-Ecology. (Accessed on 17/06/2011).

[34] Suchada, J., S. Bunrathep and T. Songsak. 2010. Nutrients And Minerals Content Of Eleven Different Samples Of Moringa Oleifera Cultivated In Thailand. Journal of Health Research. 24(3): 123-127

[35] Singh, S.V. and D.M. Pandey. 2011. Human Health Risks due to Cement Dust Exposure. Rajasthan State Pollution Control Board, Policy Brief No 2. www.rocb.nic.in. (Accessed on 13/09/2011).

[36] Steven, D. E. 2011. Herbal Medicine Overview. University of Maryland Medical Center, 22 S. Greene Street, Baltimore. www.umm.edu/altmed/articles/herbalmedicine-000351.htm. (Accessed on 24/03/2013).

[38] Worrell, E., L. Prince, N. Martin, C. Hendriks and L. O. Meida. 2007. Emissions From the Global

[39] Cement Industry. Annual Review of Energy and the Environment. 26:203-229.

[40] Wu, C.G., R.A. Chamuleau and K.S. Bosch. 1996. Potential effects of Silymarin on Rat Liver injury induced by Ischemia. Virchow Archives B. 64(5):259 - 263

[41] Zaki, M.S., S. Mastafa and I. Awad. 2010. Some studies of lead toxicity in marino sheep. Journal of American Science. 6: 128-131. 